\title{
"Under moral obligation to stay:" Herbert R. Christie and the Origins of Forestry Education at the University of British Columbia, 1910-1933
}

\author{
Mark Kuhlberg, Laurentian University
}

\section{ABSTRACT}

Judging from the contrasting state of affairs at the forestry schools at the University of Toronto and the University of British Columbia, it is difficult to believe the situation that prevailed roughly eight decades ago. Today, UBC's program is thriving whereas the forestry school at the University of Toronto is but a shadow of its former self. Exactly the opposite was true in the early twentieth century. Ironically, forestry education at UBC owes its existence to the profound commitment that Herbert Read Christie, a graduate of Toronto's Faculty, showed to it in the years after the First World War. This article explores Christie's role in building the UBC forestry school, and sheds light on the development of forestry as an academic discipline in Canada.

\begin{abstract}
RÉSUMÉ
En regard de l'évolution académique des écoles de foresterie de l'Université de Toronto et de l'Université de Colombie Britannique (UBC), il est difficile d'imaginer la situation qui existait il y a environ quatre-vingts ans. Alors que de nos jours, le programme de UBC s'avère florissant, les études en foresterie de l'Université de Toronto font piètre figure en comparaison de ce qu'elles étaient au début du XXe siècle où l'inverse prévalait. Il est ironique de souligner que le programme de foresterie développé à UBC, peu après la fin de la Première Guerre mondiale, est l'œuvre de Herbert Read Christie, un diplômé de l'Université de Toronto en ce domaine. Cet article explore le rôle marquant joué par Christie dans l'implantation de cette école et de l'essor académique de cette discipline au Canada.
\end{abstract}

Judging from the present state of affairs at the forestry schools at the University of Toronto and the University of British Columbia, it is difficult to believe the situation that prevailed roughly eight decades ago. Today, UBC dwarfs the operations of its eastern rival, boasting an undergraduate enrolment of 500 and a faculty complement of 60; a recent review of its activities declared that it is "one of the strongest forestry programs in the world. It has a large, diverse, and talented faculty, [and] the largest graduate program that we are aware of in North America." In contrast, the forestry 
school in Toronto terminated its undergraduate programme in 1993, its teaching complement has been reduced to roughly one dozen, and its graduate student body numbers under 100. But it was not always thus. In the early 1920s, the Faculty of Forestry in Toronto was the country's marquis program, whereas UBC's forestry school stood at the other end of the spectrum. Established in 1920, it barely survived its nascent years. The irony of the situation today is that forestry education at UBC owes its existence to the truly profound commitment that Herbert Read Christie, a graduate of Toronto's Faculty, showed to it in the years after the First World War.

Christie's crusade on behalf of UBC's forestry school is significant for several reasons. It sheds light on a unique aspect of the transformation that universities underwent during the late 1800 s and early 1900s. Whereas the battles to create new programs and departments were most often waged over the academic merits of a particular subject or the credentials of those purportedly qualified to teach it, no such discourse engulfed Christie's campaign at UBC. This absence is all the more surprising when one realizes that he had neither previous teaching experience nor a graduate degree. Instead, the conflict was fought over money by a handful of university faculty members and administrators, with Christie standing out among them. This tale is also important because it fills an integral lacuna in the history of forestry's development as an academic discipline in Canada by highlighting the remarkable ethos that drove its earliest pioneers. They conceived of their work as a public service of the highest order. Teaching Canadians about forestry was their moral obligation, one to which their career goals and aspirations would have to take a back seat. As a result, the early years of forestry education at UBC tell the remarkable story of dedication on the part of its progenitor, H.R. Christie, and the willingness of some academics at this time to advance their chosen fields of study even at great cost to their personal welfare.

The Macdonald and Laurier eras witnessed major developments in Canada, some of which deeply affected the country's university campuses. They had been established as bastions for protecting the lofty intellectual traditions of western culture, but by the eve of Confederation this position was being challenged. The period's utilitarian thinking gave rise to the idea that universities could and should serve a practical purpose. This was particularly true of scientific fields, in which there was an increasing emphasis on devising everyday applications for knowledge.

This movement fostered significant anxiety on and off campus, however. In Ontario, professions such as law and medicine, for example, had begun teaching

\footnotetext{
* I would like to acknowledge the assistance of H.R. Christie's family, especially Patricia A. Christie, who provided information about his life after he left UBC. I was only able to locate Christie's descendants because of the kindness of Walter Nassichuk, Geological Survey of Canada (Calgary). Thanks Walter, for your help and encouragement! I would also like to thank Dr. Sara Burke for her immensely helpful feedback, which was crucial to situating Christie's story within the history of education literature. In addition, the archivists at the University of Toronto Archives and the University of British Columbia Archives were, as always, of great help to me as I carried out my research.
} 
their crafts to new generations of practitioners long before universities had arrived on the scene. They had done so through either lengthy apprenticeship programs or their own, independently-operated schools. Proponents of this traditional approach saw little need to change it, and often openly questioned the suitability of universities to undertake professional education. In addition, there were those occupations that were still in their infancy and lacked the social status to be considered one of the learned professions; there was no place for such vocations on campus. Moreover, all were not smitten with the idea that institutions of higher learning were the appropriate venues for providing practical education. While these conservative thinkers appreciated how Canada's robust growth around the turn of the twentieth century had rightly fuelled calls for the country to devote more attention to research, they argued that universities ought to retain their long-standing esoteric focus. Their case was strengthened by the perception that professionals such as engineers were really nothing more than glorified craftsmen who had no rightful place in ivory towers. This uneasiness was manifested on many campuses in both the United States and Canada by the decision taken by many universities to establish the continent's first "Schools of Practical Science" (i.e., engineering) at arms-length from their own operations.

Nevertheless, by the early 1900 s, a number of professions had been seamlessly incorporated into the university's fabric. This process was greatly facilitated by the widespread social acceptance and respect that many professions had acquired by this time. It was much easier to establish a school for training dentists, for example, after this group had convincingly demonstrated the utility of its work and established its own association. With these credentials behind it, its members were viewed as meriting the title "professional."

Forestry was still years away from reaching this echelon in Canada at the turn of the twentieth century. Ushered in on the back of the North American conservation movement of the late 1800 s, it had benefited from a growing push to maximize the benefits accruing from exploiting natural resources. Beginning in the $1880 \mathrm{~s}$, both the United States and Canada convened major forestry conferences, but a few decades later there were still merely a dozen foresters in Canada. They had yet to demonstrate the efficacy of their work, and they lacked a professional organization to which only accredited members belonged. Moreover, there was no powerful political constituency that was demanding that meaningful forestry measures be implemented in the woods by specialists trained in the field. ${ }^{1}$

Although the desire to capitalize on the harvesting efficiencies that foresters could deliver generated calls in Canada for introducing forestry as a subject at university, the struggle to establish the country's first forestry school poignantly illustrated the limited nature of this support. Numerous groups and individuals had argued for Ontario to begin training foresters, largely because of concerns over the province's diminishing supply of pine trees. Yet officials at the University of Toronto, which would eventually host the forestry school, were hardly enamoured of the idea. While they fought an intense battle against Queen's University in Kingston for the right to win the forestry school, they — unlike their colleagues at Queen's - were motivated strictly by a desire to deprive their eastern rival of this privilege. More importantly, 
the Ontario government had little interest in creating a forestry school, as it feared the influence the school's graduates would wield in shaping policy. Control over timber had been one of the most powerful instruments that the ruling government had employed to reward friends and punish enemies. The politicians thus only agreed to establish the forestry school in 1907 after a Royal Commission literally demanded they do so. Not surprisingly, the Ontario government refused to employ all but one of its graduates for the first dozen years of its existence and ignored its message about adopting prudent forest management practices.

The first dean of Toronto's Faculty of Forestry, Bernhard E. Fernow, recognized the rough seas that he would have to navigate, and this cognizance fundamentally shaped his pedagogy. A Prussian immigrant, Fernow had arrived in the United States in the 1870 s as North America's first practising professional forester. After working for the American government, he left to start the continent's inaugural forestry school at Cornell; in 1907 he was invited to Toronto to perform the same function for Canada. Acutely aware of the paucity of support for practising true forestry in Ontario in particular and Canada in general, Fernow committed during his twelve years as dean (1907-1919) to producing the best possible graduates in terms of technical knowledge and, perhaps more importantly, character. He took many steps to achieve this latter aim, not the least of which was his adherence to both a strict code of discipline and rigorous academic standard (his students' attrition rate averaged nearly 50\%). Furthermore, he made certain that he and his colleagues wove a moral message into their lectures. Working in the forestry field in these earliest days of its existence in Canada was not simply a job but a conscious decision to devote their working lives to furthering "the cause." Fernow's known penchant for inculcating this ethos of public service in his protégés no doubt made his campaign that much easier because it ensured that only those who were receptive to this "calling" enrolled in his school. The upshot saw practically every one of his graduates leave the Faculty in Toronto with a fervent commitment to do whatever was needed to further the broader forestry campaign.

Fernow had served no more than a few years at the helm in Toronto when university officials in British Columbia began planning to establish their own forestry school. The country's other provinces that boasted strong forest industries had established such institutions - New Brunswick in 1908 and Quebec 2 years later, and all signs indicated that British Columbia was moving in that direction in the run-up to the First World War. The University of British Columbia would officially open in 1915, and the original plans for the layout of its future site at Point Grey in Vancouver included a large experimental forest, a forest reserve and a building designated for a "Faculty of Forestry." The iconic Harvey Reginald MacMillan was on the vanguard of the movement to establish a forestry school at UBC. After earning his Master of Forestry from Yale University, in 1912 he became British Columbia's inaugural Chief Forester in its freshly-minted Forest Branch. From that point forward, "HR," as he later became known, vociferously lobbied officials within the provincial government and UBC to establish a forestry school on its campus. ${ }^{2}$

While UBC and the BC Forest Branch were fully committed to founding the 
forestry school, time and time again during and immediately after the First World War the money was not available to do so. Frank F. Wesbrook and Reginald W. Brock, respectively the university's president and dean of Faculty of Applied Science, unquestioningly endorsed MacMillan's proposal to begin training foresters at UBC. So, too, did the university's Senate and Board of Governors, and a number of local community organizations. All the while, MacMillan kept feeding Wesbrook and Brock data on the anticipated cost of establishing a forestry school and information about how other institutions had done so. Nevertheless, UBC could not convince the provincial government to allocate the money to establish it. As the university's Board of Governors repeatedly declared, it was prepared "to establish a [forestry] School as soon as the necessary funds are available," which they were not. ${ }^{3}$

But this was not entirely true, as UBC's senior officials placed a few conditions upon creating a forestry school. In response to another push to establish it in the fall of 1916, President Wesbrook offered his support for the campaign but insisted that the university's authorities "must be guided in their actions by the amount of financial and legislative support which they are able to secure" for the initiative. Roughly six months later, Wesbrook repeated this message. He informed Martin A. Grainger, BC's Chief Forester, that he was anxious to do all he could to realize the project but "we do not wish to have the University work in other directions curtailed." Then in late 1917, Wesbrook told MacMillan that the latter's presence as its inaugural director was essential if the project were ever going to get off the ground. MacMillan was amenable to leaving his government post to take on the job, and the university's Board of Governors agreed to MacMillan's demand that he receive a relatively high salary of $\$ 5,000$ to act as its first dean. ${ }^{4}$

The forestry school enjoyed a false start in 1918, and when the province finally loosened its purse strings enough to provide for the school's founding, MacMillan was no longer available to perform the task. UBC offered a "short course" in forestry for returning veterans in the fall of 1918 (to train them to become rangers with BC's Forest Branch), but only because Ottawa funded the effort. The course died the next year when the dominion government refused to support it. Then, in mid-1920 UBC learned that the provincial government was finally going to ante up the funds needed to cover the forestry school's start-up costs. By then, however, MacMillan had organized a new lumber export business with British entrepreneur Montague Meyer, one that became the antecedent to his "Empire of Wood." As a result, the dean of the Faculty of Applied Science, Reginald Brock, headed "back east" in the summer of 1920 to find someone to organize the forestry school. Brock spoke to officials at the University of Toronto, who wholeheartedly recommended several men for the job. This group included two members of the Faculty of Forestry in Toronto, namely J.H. White and W.N. Millar, but they were uninterested. The other person was Herbert Read Christie. ${ }^{5}$

Christie had many of the requisite credentials for the position despite his lack of teaching experience. A native of Amherst, Nova Scotia, Christie had graduated from the Ontario Agricultural College in 1908 and Faculty of Forestry in 1913. As a student in Toronto, he had performed brilliantly, earning at a time when they 


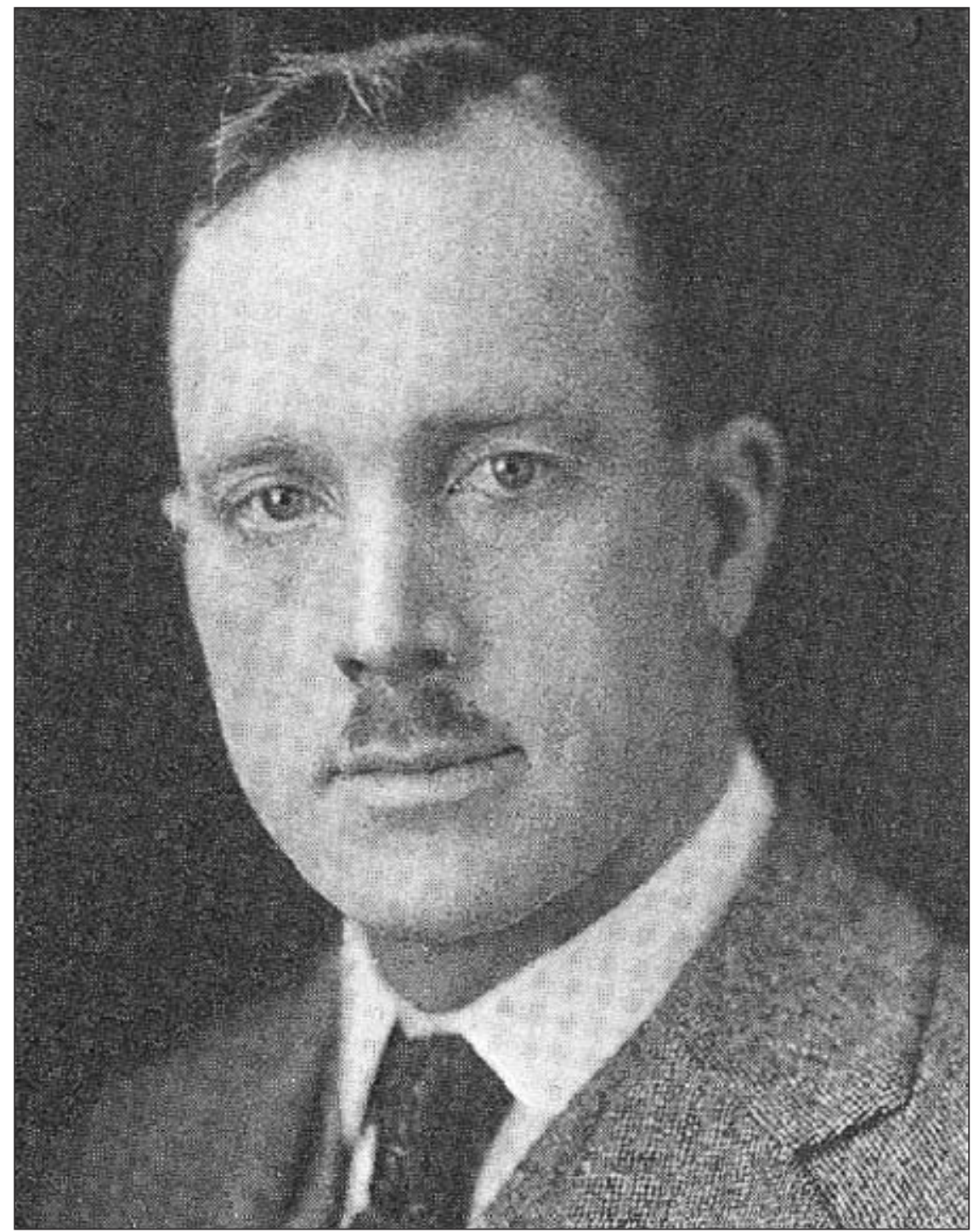

Fig. 1: Herbert Read Christie, Head of UBC's Forestry School, 1921-1933 (Courtesy of University of Toronto, Archives, A1972-0025/001(107)).

were reserved for only the brightest students. After graduation, he began working for the BC Forest Branch, and then enlisted in 1916. He served on the front lines for nearly two years and another eight months with the Canadian Expeditionary Force in Siberia. After returning to BC, he was promoted to Assistant Chief Forester of its Forest Branch. He was thus well versed in the issues that confronted those working in the province's woodlands. ${ }^{6}$ 
Through his work as a student and forester, Christie had displayed the same moral commitment to "the cause" that marked the graduates from Toronto's forestry school. Its founding dean, Bernhard Fernow, commented upon Christie's zeal in the spring of 1919 after he had heard that Christie's native Nova Scotia was looking for a provincial forester. Considering Fernow personified tough love, the plaudits he heaped on his former student at this time were more than a little out of character. He informed Christie's father of the opportunity and noted that "there is no better man in the world than your son to take up this patriotic work." Fernow then encouraged Christie the younger to take up the post by reminding him of the "patriotic fervour" he had demonstrated when he had "entered the Faculty with the idea of advancing forestry in Canada as a life work" and the chance was now presented to him to realize this aim. ${ }^{7}$

Christie did not pursue this opportunity, but he demonstrated his "patriotic fervour" to his vocation through his actions in accepting the offer to head up BC's new forestry school. Although the provincial government had authorized UBC to spend the funds to establish a forestry school during the 1920-1921 school year, and it had settled upon Christie as the best candidate for the job, he refused to take on the new assignment until he had finished tying up loose ends within BC's Forest Branch. This meant that it was only on 1 December 1920 that he received the formal offer to head up UBC's forestry school, which was scheduled to open merely one month later! Nevertheless, President Klinck congratulated Christie on his new job and asserted that "the possibilities for building up a strong Department of Forestry in the University of British Columbia are of the best." 8

Despite these reassurances, Christie entertained grave doubts about his ability to fulfil his new obligations, and his anxiety was a function of more than simply the lack of time he had to prepare before embarking on his academic career. In midDecember 1920, he confided his innermost thoughts in Clifton Durant Howe, the new dean of the Faculty of Forestry in Toronto. "Sometimes I have a feeling, a sort of perplexed surprise," Christie began, "about the unexpected positions in which Fate seems to lead one; but moralizing is one of my besetting sins so I will go on at once to the object of this letter." Christie explained that he had agreed to organize UBC's forestry program, but he wished with all his heart that he could devote his undivided attention to it at this time. "In fact," he admitted, "I would like to have six months or a year to prepare, but circumstances make it necessary for me to carry on in the Forest Branch until the end of the year." To facilitate his work at UBC, he asked Howe to send information about the different courses the Faculty in Toronto taught. In a hand-written post-script, Christie philosophized, "Fools rush in where angels fear to tread.' I wish one of your angels had undertaken this job. I didn't exactly rush in but I think I was kind of pushed in. It's like the war - nothing was further from my intentions when I first heard of it. I wonder if marriage comes to one the same way? I have a hollow stomach feeling every time I think of facing a class and lecturing (out of my ignorance)." 9

Howe responded by trying to assuage Christie's concerns and buoy his spirits. He forwarded Christie a list of appropriate course materials, and empathetically 
declared that he had only grown comfortable with teaching after having spent fifteen years in the classroom doing it. But, he advised Christie, it would take far less time for Christie to reach this point because of Christie's intelligence and natural ability. "Personally," the dean told Christie, "I am very glad that you have decided to teach, for I know that you can do it in splendid shape."10

While Christie received congratulatory notes and well wishes from most members of Canada's tiny clique of foresters, all of whom conveyed their belief that his excellent qualifications practically guaranteed him success in his new endeavour, Christie could simply not share this confidence in him and informed UBC's senior administrators that he accepted the post strictly on a trial basis. Clyde Leavitt, the Chief Forester for Canada's short-lived Commission of Conservation, wrote Christie a few days before Christmas to express his excitement upon hearing of Christie's appointment. Christie's reply thanked Leavitt for the good tidings, but revealed that Christie did not "feel as assured about my ability to make it a fine success as you say everyone does." Because Christie had never taught and had been out of school for such a long time, he explained that he was:

"simply undertaking the work on an experimental basis this winter. I made it quite clear to the University authorities that ... if I dont [sic] like it or if I dont [sic] feel I can handle it satisfactorily, or if the University authorities are not satisfied, we will part company. My personal feeling is that it would be better from many standpoints if a man with previous university experience could be obtained to undertake the work, and I will be quite willing to step out in favour of such a man at any time, so if you can persuade White [at the Toronto Faculty] to change his mind, you will be doing the university a good turn." 11

In the meantime, Christie did what was needed to see that UBC's Department of Forestry - with a staff of one-opened its doors in January 1921. Students could enrol in the program after having completed two years of general sciences, and a few elected to become members of its inaugural class. ${ }^{12}$

After spending less than one month in the classroom, however, Christie's selfdoubts had only deepened. Christie lamented to Howe in Toronto in late January 1921 that he detested teaching. While he valiantly attempted to attribute his dislike to his desire to work outside, the real reason was his crisis of confidence to which no one could seemingly put an end. "I wish a 'real educationalist' were in charge" of UBC's fledgling forestry school, he told Howe, and "feel overwhelmed despite your flattering remarks." Christie confided that he would "gladly hand it over to someone" if the opportunity presented itself. "Haven't you some one there [i.e., at the Faculty in Toronto] that wants the job?" he asked Howe wistfully. "Whether I'll be here next year or not I dont [sic] know yet," Christie continued. "I haven't made up my mind ... But as I said before, I know I am not really fitted for it and will be ready and willing for a real teacher to take it. This of course is confidential. I tell it to you because it concerns you and your staff and because the matter of forestry education is not settled and I want you and your staff to be thinking about it." ${ }^{13}$ 
While Christie was mired in this quagmire of self-doubt, UBC — and specifically the Faculty of Applied Science [FAS] of which his department was a part - was desperately waging its own campaign to stay afloat. The nascent FAS was in the process of ramping up its programs to provide, for the first time, specialized instruction for senior students, and this necessitated hiring more professors. Forestry, for example, needed at least one additional instructor; it would be virtually impossible for Christie to deliver the curriculum to every third and fourth year student the following year. But the provincial government, suffering from declining revenues during the economic downturn of 1920-1921, insisted that UBC cut its budget. Reginald Brock, Dean of the FAS, abided by this request but insisted that the cuts he had made were to be his final ones. Any more budgetary reductions, Brock told President Klinck in a tersely worded letter, would render "it wholly impossible to carry on the work we are, in effect, under contract to give the regular undergraduates who are enrolled in, and already taking, the courses offered in applied science." Although Brock had drawn a line in the sand, before he had done so he had chopped the forestry's school's new professor from his budget. Christie would be forced, somehow, to soldier on alone. ${ }^{14}$

It was in this tumultuous environment that Christie decided to throw in the towel, a decision he made - at least at this point — with a clear conscience. In late June, he submitted his resignation to UBC. The main reason, he confessed to J.H. White, a professor at Toronto's Faculty of Forestry, was his lack of confidence in his teaching ability. "I don't honestly feel that I could do it as I think it ought to be done, at present, and especially single handed, as is the prospect," he despaired. He reminded White that he had taken the job on a strictly "experimental basis" and had thus "retained moral freedom of action," and pleaded with White to head west to take over UBC's forestry school. ${ }^{15}$

Christie considered the matter closed but Dean Brock did not, and the latter took steps to rectify the situation. Brock had been fighting tooth and nail for the FAS's interests, including hiring another forestry professor, and word that Christie intended to abandon his post could not have come at a worse time. News of this defection would completely undermine Brock's campaign, and he would not brook it. He wrote Christie a firm letter in which he euphemistically explained to his forestry colleague "the inconvenience that might result from this retirement at the present time" and his expectation that Christie would honour - at a minimum - the term of Christie's contract, which ran until the end of March 1922. Christie buckled under this pressure and agreed to stay on, but with an important caveat. As he put it to UBC's president, he would withdraw his resignation for the time being "or at least postpone it until you have arranged for a successor which I believe you will be able to do by the end of the College year." 16

No sooner had Christie made this promise than he realized how vulnerable it left him. UBC's senior administrators could easily feign an effort to find his replacement, thereby leaving Christie no choice but to remain at the helm of the forestry school. And in fact, he suspected this is exactly what had already happened over the summer of 1921, a period during which he had expected UBC to seek actively his successor. 
In a letter to Professor White in Toronto, Christie explained what had happened and added that both the university's president and FAS's dean were now in England and would be there until the beginning of term in late September. Before they had departed, they had left word that "it would be rather awkward for them to get a successor before the term opens and requested me to carry on in the mean time." The problem, Christie underscored, was that he did "not know how hard they [had] tried to get some one else. Perhaps not at all."17

With Christie desperately seeking a means of escaping UBC, serendipity smiled on him. Over the summer of 1921, C.D. Howe, Dean of the Faculty of Forestry in Toronto, informed Christie that there was a teaching position waiting for him at his alma mater. Taking the job, Howe stressed, would allow Christie to cut his teeth under the tutelage of seasoned colleagues, teach a few subjects instead of all of them, and practically guarantee Christie well paid summer work with the Ontario government. After visiting Howe to discuss the opportunity in September, the formal offer to start work in Toronto on 1 July 1922 landed on Christie's desk the following month. ${ }^{18}$

Although Christie was tormented by the choices that now presented themselves to him, he found the prospect of heading back east too good to resist, news that delighted Howe. Christie wrote the dean on the last day of November to accept the job and to apologize for having taken so long to respond. "When it came to the pinch, to saying that I'd leave B.C.," Christie divulged, "I weakened - every time - until now. It's sentiment. I did not know it was so strong - because on one or two occasions before I have contemplated leaving the province — but I suppose it only develops its full strength when contemplation has to be turned into action." Christie also implied that he fully expected his replacement would be found before the beginning of the 1922-1923 school year. Howe was ebullient with Christie's decision, and asked Christie to forward a photograph of himself and a biography so that Howe could publicize the news as soon as it became official. ${ }^{19}$

In fact, officials in Toronto were so excited by word that Christie was coming to join their Faculty of Forestry that they prematurely feted his arrival in a manner that spoke volumes about their high regard for him. On 4 January 1922, Howe wrote Robert Falconer, the University of Toronto's president, to confirm that the Faculty wished to hire Christie, and that he and his fellow forestry professors in Toronto had always regarded Christie "as one of the very best of our students. Only one other graduate surpassed him in attainments in undergraduate work." Howe added that Christie was, inter alia, "gentlemanly in manner and a gentleman at heart." Falconer shared Howe's positive perspective on Christie, and announced Christie's appointment at the Faculty's annual banquet in early February. ${ }^{20}$

The problem with all the celebrating was that Christie was in no position to formally accept Toronto's offer. He had promised not to leave UBC until his successor had been selected, and none had yet been found. Fearing that the university's officials would not uphold their end of the bargain, Christie launched his own campaign in March 1922 to find his replacement. He began contacting senior ranking foresters to inquire about potential candidates and his colleagues' views on them. Disappointed 
when he was reminded that no one on staff in Toronto would take up the posting in Vancouver, his spirits were lifted by word that there were several possible suitors in industry and government. ${ }^{21}$

Just as it seemed his stars were aligning, Christie's universe imploded. The difficult economic times had compelled the British Columbia government to deliver in the spring of 1922, just as it had one year earlier, a disappointingly small budgetary allocation to UBC for the upcoming fiscal year. For Reginald Brock, the hard-nosed dean of the Faculty of Applied Science, this news meant that UBC had arrived at the Rubicon. To his mind, it was inconceivable to accept this state of affairs, as it would prevent several departments over which he presided — including forestry - from hiring the necessary staff to ensure that their students would be able to complete their degrees in Vancouver. "Any step backward," he defiantly declared in his briefing notes on the matter to Leonard Klinck, the university's president, "would seriously affect the faculty and the whole university. We must take this one last step forward or the Faculty will receive a blow from which it will not recover in two decades ... If money cannot be obtained in any other way to fulfil our obligations to our students," Brock brazenly threatened, "I would respectfully request the opportunity of tendering my resignation." Attesting to the gravity of the situation was the discussion Klinck had with BC's Minister of Education in late March 1922. The options they considered in light of the limited financial resources available included abolishing the university and eliminating one or more of its faculties. ${ }^{22}$

This perilous situation had completely recast the variables in Christie's life, and he relayed the bleak news to Howe in Toronto. "A very disturbing situation has arisen here in connection with the university finances," Christie's lengthy memorandum on the subject began. From his recent meeting with President Klinck he had learned that "there is much less money than is needed to carry on with, and something will have to be shelved, some drastic step will have to be taken. If the forestry professor leaves," Christie stated despondently, "there is a strong probability that forestry will be the victim or one of them, because it will be so easy to simply drop it instead of engaging someone else. For that reason he [i.e., Klinck] said he had never formally brought my resignation before the senate though it is known unofficially, and therefore it has not been acted on." Christie explained that, during his meeting with Klinck, the president had not leaned on him as Brock and others had done one year earlier. Instead, Klinck had simply described the "critical" nature of the situation, particularly for those in the Faculty of Applied Science. As UBC's newest faculty, it would probably be hit the hardest because it still required more money to hire new professors each year until all its courses were established.

Christie then hit upon the crux of the matter, namely that his devotion to the forestry cause would now be paramount in determining his course of action. "There seemed to be only one thing for me to say," Christie stated, "that if the continuance of the forestry course here is contingent on my staying another year why of course I shall have to stay - and I said I thought that you would agree too that that is the only thing I could do." Christie recounted how he had told Dean Brock roughly one year earlier that he had wished to leave but had felt "duty bound to stay" until 
Brock could find a suitable replacement. "I meant that," Christie confessed, "but at the same time never expected that such a situation wuould [sic] come about, nor did he. It all seemed very simple then." Now, Christie explained all bets were off: "unless an unbroken front is maintained for the time being, it is more than probable that the department of forestry will die." Moreover, even if Christie stayed, there was no guarantee that the Sword of Damocles that hung above the Department of Forestry would not fall. Its only hope, however, lay in not making waves at this crucial juncture. "No doubt this is very irritating for you," Christie stated apologetically to Howe. In light of the situation, Christie recommended that Howe begin looking for someone else to fill the opening in Toronto.

Christie closed his letter to Howe with a few lines that poignantly captured the unimpeachable spirit that moved him, one for which Howe held the utmost respect. "The upshot of the matter here may leave me out of a job," he conceded, "but I am not inclined to worry about that nor to balance a job against the welfare of the department and the university. I feel that the thing ought to be kept going somehow until it is safely established, and I am willing to do what I can to help, even it if is against my inclinations and may cause me some inconveniences." While Howe was deeply disappointed by Christie's dreadful news, he could not help but respect Christie's ethics and hope that the UBC professor would end up in Toronto. "I admire you more for the stand that you have taken," Howe commended his western colleague, and "I shall pray that things turn out so that you can come to us." ${ }^{23}$

Christie, too, entertained a faint hope that he would be freed from the fetters that held him in Vancouver. In mid-June, just as he was packing to head for the summer to the Queen Charlotte Islands, he learned that both Dean Brock and President Klinck were travelling to Ontario to find replacements to fill a number of openings at UBC. And, unlike a few years earlier when Christie was first organizing the forestry school in BC, there was now a solid handful of potential candidates available in both Canada and the United States to succeed him. W.N. Millar, a seasoned forestry professor in Toronto, was at the top of the list, and Klinck had committed to approaching Millar about the job. ${ }^{24}$

But the beginning of the 1922-1923 fall semester brought devastating news to Christie, including the realization that his university's senior administrators had played him. Christie's work in the bush that summer had left him incommunicado. Consequently, he had not received the telegram that President Klinck had sent him in mid-July that explained that Millar had declined the offer to come to UBC. Thereafter, it appears that Klinck and Dean Brock had simply given up the hunt for Christie's replacement, and banked on Christie returning to his job in Vancouver. Christie was floored by this news when he returned to the lower mainland in mid-September. "When I left here last June," Christie explained to Howe in a heartfelt missive, "I did not expect to be teaching again this winter. I thought that Brock would succeed in getting Millar or some other to take the work here and that you would likewise make sure of someone else instead of me because of the indefinite and unsatisfactory nature of my acceptance." Christie was thus dumbfounded to learn from President Klinck that Klinck had not succeeded in getting Millar or anyone "and that he was 
still counting on me, and the promise I made last spring that if he was stuck for a man I would stay rather than see the course closed." Christie explained to Howe that "the president had a hard fight to get the forestry estimate through, so he said, and if the position had been vacant he would have failed. However he did get it and then I understand that he and Brock spent some time looking for a man. Just how much they spent I do not know but I do not think that they really looked very hard or they would have secured someone." Christie believed his suspicions were well founded because he had learned that neither Brock nor Klinck had visisted Howe while they had been in Toronto scouting out potential candidates for jobs in BC. In any event, Christie considered it water under the bridge. "The upshot," Christie bemoaned to Howe, "was that I was held to my promise and did not feel that I could go back on it after the work he [i.e., Klinck] had done to retain the course in the curriculum." Christie apologized profusely for having caused Howe so much trouble, and assured Howe that "I would rather be working with you at Toronto than to be in charge of work here for which I am so ill prepared." 25

For Howe, this news was equally distressing. He had believed all along that Christie would find a way to fill one of the two positions that the University of Toronto had granted its Faculty of Forestry at this time. Now, at the eleventh hour, Howe was left with the position but no one to fill it, a scenario that gave the university administration the opportunity to cancel it. ${ }^{26}$

Howe also shared Christie's view that UBC's senior administrators had exploited Christie's virtu. When Howe informed the University of Toronto's bursar about the situation, the dean initially did so by describing how university officials in Vancouver had held Christie to his promise to remain at his post if needed. Now, Howe stated, it would be more accurate to depict the situation as one in which "Professor Christie feels that he is under moral obligation to stay under the circumstances." Likewise, when Howe informed a fellow forester that officials at UBC had not been able to find a successor for Christie, he hypothesized that "just how energetic they were in trying to find a man to take Christie's place might be an interesting subject for investigation." 27

Christie had little choice but to pick up the pieces, and for a little while it seemed as though his commitment would finally be rewarded. In October 1922, UBC's senior administrators bowed to Dean Brock's demand that Forestry be awarded another position to enable it to deliver its courses. The university hired - albeit on a temporary basis - F. Malcolm Knapp, a logging engineer specialist who began his forty-one year career at UBC that fall. The following spring, UBC granted Christie a raise, and promoted him from Associate to Full Professor and dropped "Acting" from his title as Head of the Department. Around the same time, his school graduated its first cohort (of two!), and over the next few years, the school's student body rose slowly but steadily. By 1926, it numbered just over one dozen. No doubt the attractiveness of earning a forestry degree at UBC had grown because Christie's school, much to his delight, had taken up residence in new quarters. ${ }^{28}$

Over the rest of the decade and into the early 1930s, Christie continued to fight for "the cause." During his reign as head of the department, it established the UBC 
Forest Club, which began publishing The UBC Forest Club Annual, and he introduced field trips to the curriculum; all were concepts seemingly modeled after similar initiatives launched by the Faculty in Toronto some years earlier. He also successfully lobbied the British Columbia government and UBC's president to secure a demonstration forest on campus. Finally, he served as both BC's representative in the Canadian Society of Forest Engineers (his profession's association) and a member of the editorial committee for its organ, The Forestry Chronicle. ${ }^{29}$

Behind these successes, however, Christie - and his colleague Knapp-were acutely aware of their forestry school's tenuous standing at UBC and in the provincial legislature. With the university's total enrolment hovering around 2,000, overseeing a program with a student body that could often be counted on both hands - and still have a finger or two left over! — was hardly cost effective (between 1921 and 1933, Forestry at UBC annually graduated an average of fewer than three students). Moreover, the university's administration did not consider their forestry school to be a high priority during the 1920s, a perspective it made clear to Christie on a number of occasions. In 1925, for example, they rejected his request for a meagre sum to offer as an honorarium to entice Dr. Carl A. Schenck, one of North America's iconic foresters who was visiting Vancouver, to deliver a guest lecture to his students. As a result, Christie and Knapp were compelled to sustain their program during this period by using the money they raised by selling the timber — particularly firewood — their students harvested from the University Forest. ${ }^{30}$

What must have been particularly vexatious for Christie was the knowledge that he was not even graduating bona fide foresters. The chilly reception the province's lumber industry had given the forestry school, the school's close association with UBC's engineering departments, and the fact that Christie's graduates were being hired to run logging — not forestry — operations had fundamentally influenced the curriculum Christie had developed. It focused on teaching students how to improve the efficiency with which their employers were cutting trees in BC instead of managing woodlands on a sustainable basis. In fact, Christie’s students graduated as "forest engineers" and not "foresters." While he accepted that this was the only reasonable approach to take in the short term, he had faith that his courses would one day aim primarily at teaching students about "the production of a new crop." 31

This hope had sustained Christie enough for him to endure the challenges during the late 1920s, but they had taken their toll on him, and the events of the early 1930s conspired to leave him enervated. During these years, the combination of deteriorating relations between UBC and the provincial government and the desperate economic times that were attendant upon the beginning of the Great Depression came within a hair of destroying UBC. Over the course of 1930-1933, it saw its annual grant shaved 60\%, and an "independent" commission appointed in April 1932 even suggested it would be best to close the university and instead offer scholarships so students could pursue post-secondary education out of province. Faced with this spectre, UBC's senior administrators recommended eliminating the small third and fourth year classes from all departments. Not only would this move have sounded the forestry school's death knell, Reginald Brock, dean of the Faculty of Applied Science, 
advised UBC's president that, "if any Departments have to be cut, the first ones to be closed down should be those that will not affect the remaining courses, viz. Nursing and Health and Forestry." Although Brock adamantly protested against taking such a Draconian step, all factors pointed to the forestry school's days being numbered. ${ }^{32}$

In the midst of this latest doom and gloom - staff were being fired by the handful in the spring of 1932, Christie cried uncle. In late July, he submitted his unconditional resignation effective the end of the 1932-1933 school year. ${ }^{33}$

Over the fall of 1932, Christie elaborated on the rationale behind his decision. In his annual report for UBC's Department of Forestry, he stressed that a string of foresters in both industry and government had been fired recently, and there was no reason to believe that job prospects for his graduates would improve in the foreseeable future. Under these conditions, he argued that there was utterly no need for the existence of three forestry schools in English Canada. He thus recommended that resources be concentrated in Toronto, where "the largest and best equipped school" was already located. He reiterated these forlorn views in a letter to Howe in late October. He expressed his fear that UBC's Department of Forestry would be eliminated because it was so "small and young. In view of these cercumstances [sic]," he despaired, "and my feeling that the small number of students does not justify the expense of the Department, I gave my resignation last spring and shall be leaving after the spring term 1933." Howe responded by commiserating with Christie's situation and concurring with his view that two of English Canada's three forestry schools were redundant. ${ }^{34}$

By all accounts, Christe left UBC a mere shell of his former self. In early 1934, Dean Howe in Toronto had been asked to recommend candidates for a forestry job in Nova Scotia. Knowing of Christie's Maritime roots and earlier desire to cultivate them, Howe wholeheartedly recommended Christie for the position. His reference letter outlined how Christie had been "up against a hard proposition in British Columbia trying to make a forestry school with entirely inadequate funds and with considerable scepticism on the part of the lumber industry as to any need of foresters in $[\mathrm{BC}]$." Howe also noted that over the last few years Christie had "been much discouraged and consequently suffered in health. The combination of the two things led to his resignation. I saw him in his home last summer and noted his discouragement." But, Howe stressed, he knew that Christie had "splendid stuff in him and I feel very sure he would succeed if he could once get a new start. I feel sure also that getting away from $[\mathrm{BC}]$ and going back to his native province would aid very much in his recovery of confidence in himself. I am aware that this is not the ordinary type of recommendation," Howe stated candidly, "but I want to be sure that you understand Christie's situation. He was always inclined to be introspective and self analytical and the combination of things piled up in $[\mathrm{BC}]$ so heavily against him that it has increased that tendency." 35

Nothing came of this opportunity, and although Christie would never practise forestry in Canada again, he remained a forester at heart. He took up farming in the Fraser Valley after leaving UBC, but the Depression years proved immensely difficult for him and his family. When war was declared in September 1939, he was one of 
the first to enlist, joining the Forestry Corps as a Captain. Stationed in Inverness, Scotland, for most of the conflict, he helped manage the harvesting of the local pine forests for the war effort. ${ }^{36}$ After returning to British Columbia in the mid-1940s, he eventually settled in Fanny Bay on Vancouver Island, where he started a successful co-operative oyster farm; he lived there until his death in 1970 . He and his wife had five children, one of whom he named Martin Grainger. It was no coincidence that the Martin A. Grainger had been one of British Columbia's pioneer foresters. He had drafted the province's original Forest Act, served as its second Chief Forester from 1916 to 1920 (Christie had been his assistant over 1919-1920), and been an outspoken advocate of establishing the forestry school. Christie's gesture was a telling testament to the depths of his devotion to the forestry cause. ${ }^{37}$

UBC's Department of Forestry barely survived Christie's departure, but its fortunes enjoyed a dramatic upturn just as it seemed all hope was lost. Malcolm Knapp, who took over from Christie as head of the department, was appointed merely on a month-to-month basis through 1933-1934, and the forestry school was only able to deliver its curriculum by relying heavily on volunteer labour from benevolent members of the BC Forest Branch. Then, almost miraculously, the ground shifted. UBC's Faculty of Applied Science undertook a review of its programs in 1935, and P.M.

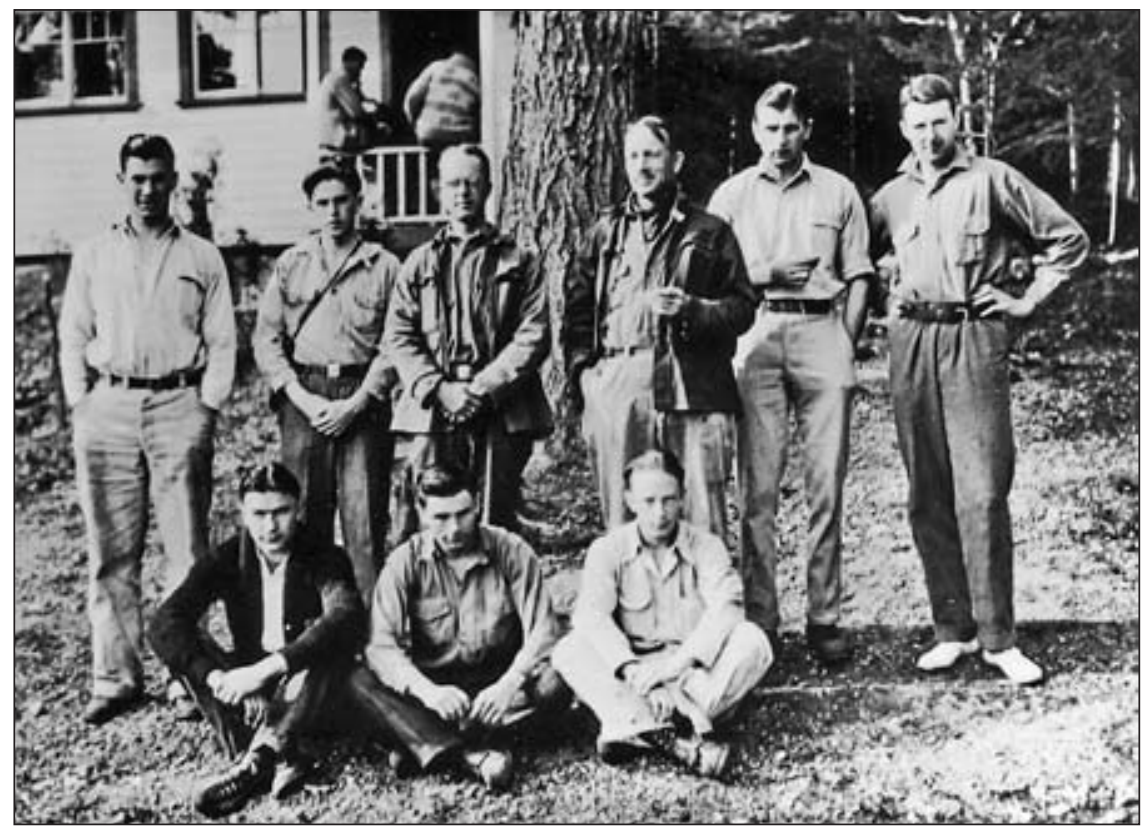

Fig. 2: Christie took his students to the BC Forest Branch's Cowichan Lake Research in April 1931. He is standing third from the right, with Malcolm Knapp to his right (Courtesy of BC Ministry of Forests and Range, Research Branch). 
Barr, a professor from the University of California, was retained to investigate thoroughly the forestry program. His report charted a bold new course for its future, one for which Christie could only have dreamt. Barr recommended that it abandon "the present curriculum in Forest Engineering ... as an exclusive approach to professional forestry employment" and focus instead of delivering a program of true "scientific forestry." Most importantly, UBC committed the resources to realize Barr's recommendations, thereby facilitating the growth of the forestry school. By 1951, it had developed enough critical mass to warrant reconstituting it as the Faculty of Forestry, a stature for which UBC's original plan had called some four decades earlier. ${ }^{38}$

None of the successes that UBC's forestry school enjoyed after Christie's departure would have been possible, however, had it not been for him. Surprisingly, his battle to retain forestry education as a part of the university's pedagogy was never waged around the typical issues that marked campaigns to introduce new subjects on campus during these years of striking developments in post-secondary education across Canada. Looking back, it is truly astounding that, in the very least, no one ever questioned Christie's academic qualifications, or rather lack thereof, for heading up a new department. Rather, the survival of the university's forestry school was strictly a matter of dollars and cents, and whether the provincial government allocated the money for this undertaking. More importantly, the story of Christie's work at UBC provides another object lesson in the unwavering dedication to the cause that imbued Canada's trailblazing corps of foresters in the first few decades of the twentieth century. As one of the first students in the country to graduate with a bachelor of science in forestry, Christie went forth into the working world with a deep-seated faith in the righteousness of his mission to act as one of his profession's disciples. His particular calling came in the form of remaining at UBC during the embryonic stage of its forestry school's development, even though his job there steadily eroded his self-confidence and it was one in which, truth be known, he had never had any interest. Nevertheless, he had acted selflessly, in the process knowingly sacrificing his interests for the sake of the "greater good." In doing so, his behaviour stands as a glowing testament to those in academia — both past and present - who consider their profession as a noble endeavour whose importance transcends concerns about personal advancement and enrichment.

\section{Notes}

1 Harry Logan, Tuum Est: A History of the University of British Columbia (Vancouver: University of British Columbia Press, 1958), Chs. 2-3; J. Harry G. Smith, UBC Forestry 1921-1990: An Informal History (UBC Faculty of Forestry: Vancouver, 1990), 4-6; University of British Columbia Archives, President's Office, 11-4, 15 October 1913, H.R. MacMillan to F.F. Wesbroook; ibid., 16 October 1913, Wesbrook to MacMillan; ibid., 11-10, Appropriations asked for by university from provincial government ... ; ibid., 11-8, 18 October 1913, MacMillan to Wesbrook; ibid., 6 November 1913, Wesbrook to MacMillan. 
2 Harry Logan, Tuum Est: A History of the University of British Columbia (Vancouver: University of British Columbia Press, 1958), Chs. 2-3; J. Harry G. Smith, UBC Forestry 1921-1990: An Informal History (UBC Faculty of Forestry: Vancouver, 1990), 4-6; University of British Columbia Archives, President's Office, 11-4, 15 October 1913, H.R. MacMillan to F.F. Wesbroook; ibid., 16 October 1913, Wesbrook to MacMillan; ibid., 11-10, Appropriations asked for by university from provincial government ... ; ibid., 11-8, 18 October 1913, MacMillan to Wesbrook; ibid., 6 November 1913, Wesbrook to MacMillan.

3 UBCA, President's Office, 11-4, 27 September 1916, Memorandum concerning School of Forestry; ibid., 11-10, 17 November 1916, T.J. Dooglake to F.F. Wesbrook; ibid., 24 November 1916, Wesbrook to W.B.W. Armstrong; ibid., 11-6, 17 November 1916 and 6 March 1917, M.A. Grainger to Wesbrook; ibid., 20 November 1916 and 7 March 1917, Wesbrook to Grainger; ibid., 11-3, 8 January 1918, D. Pattullo to Wesbrook; ibid., 11-8, 8 March 1919, H. Winkenwerder to H.R. MacMillan; ibid., 15 July and 27 September 1919, MacMillan to L.S. Klinck; ibid., 15 September 1919, Klinck to MacMillan; ibid., 18 September 1919, C. Leavitt to MacMillan; ibid., 11-5, 21 and 26 November 1919, Grainger to Klinck; ibid., Board of Governors' Minutes, 9 May and 4 July 1918 and 26 May 1919; ibid., H.R. MacMillan Personal Papers, 36-17, correspondence from 1916-1917.

4 Ibid., Senate Minutes, 3 July 1915; Ibid., President's Office, 11-10, 1 December 1916, F.F. Wesbrook to Chancellor and Board of Governors; ibid., 12 October 1916, J.D.

Gilmour to Wesbrook, enclosing 3 October 1916, Resolution; ibid., 21 October 1916, Wesbrook to Gilmour; ibid., 11-6, 13 February, 15 and 21 March 1917, Wesbrook to M.A. Grainger; ibid., 15 February 1917, Grainger to Wesbrook; ibid., 11-8, 13 February and 16 August 1917, Wesbrook to H.R. MacMillan; ibid., 11 July and 31 August 1917, MacMillan to Wesbrook; ibid., 11-4, 5 September 1917, MacMillan to Wesbrook; ibid., 24 September 1917, Extract from Minutes of Board of Governors; ibid., 11-11, 11 September 1917, Wesbrook to C. Sweeney. Curiously, at the same time as MacMillan was unofficially agreeing to take on the job at UBC, he was entertaining offers to succeed Dean Fernow at Toronto's Faculty of Forestry: see Kuhlberg, Ch. 2.

5 Logan, 6; Donald MacKay, Empire of Wood: The MacMillan Bloedel Story (Vancouver: Douglas \& McIntyre, 1982), 29-43; UBCA, President's Office, 11-8, 16 August and 13 September 1917, H.R. MacMillan to F.F. Wesbrook; ibid., 4 February 1918, Extract from Schedule V of Estimate Presented to the Government; ibid., 11-5, 4 February 1918, Wesbrook to M.A. Grainger; ibid., 11 September 1920, Grainger to L.S. Klinck; ibid., 17 September 1920, Klinck to Grainger; ibid., Reel 1(Brock), 22 June 1920, Klinck to R.W. Brock; ibid., 24 June and 5 July 1920, Brock to Klinck; ibid., Malcolm Knapp, 3, Loose Notes re: history of UBC's forestry school.

6 Ibid., President's Office, Reel 34(H.R. Christie), H.R. Christie M.C.; University of Toronto Archives, A2004-0017/008(H. R. Christie), correspondence from 1908 to 1919.

7 Ibid., A2004-0017/008(H. R. Christie), 14 May and 4 June 1919, J. A. Christie to B. E. Fernow; ibid., 22 May and 7 June 1919, Fernow to Christie.

8 Ibid., A2004-0017/008(H. R. Christie), 16 January 1920, H. R. Christie to C. D. Howe; ibid., 23 January 1920, Howe to Christie; UBCA, Board of Governors' Minutes, 20 April and 1 December 1920; ibid., President's Office, 6(31), 15 September 1920, Christie to L.S. Klinck; ibid., 21 September 1920, Klinck to Christie; ibid., Reel 34(H.R. Christie), 1 December 1920, R.W. Brock to Klinck, attached to which is Christie's curriculum vitae; ibid., 3 December 1920, Klinck to Christie.

9 UTA, A2004-0017/008(H. R. Christie), 13 December 1920, H. R. Christie to C. D. Howe.

10 UTA, A2004-0017/008(H. R. Christie), 27 December 1920, C.D. Howe to H. R. Christie. 
11 Ibid., 31 December 1920, H.R. Christie to C. Leavitt.

12 Ibid.; UBCA, President's Office, Reel 13(C), 26 January 1921, H.R. Christie to Registrar.

13 UTA, A2004-0017/008(H. R. Christie), 29 January 1921, H.R. Christie to C.D. Howe; UTA, B1983-0022/002(107), 24 February 1921, Christie to J.H. White.

14 UBCA, President's Office, Reel 1(FAS 1921-1922), 16 November 1920 and 21 May 1921, R.W. Brock to L.S. Klinck.

15 UTA, B1983-0022/002(107), 14 June 1921, H. R. Christie to J. H. White; UBCA, Board of Governors' Minutes, 27 June and 25 July 1921.

16 Ibid.; ibid., President's Office, Reel 34(H.R. Christie), 12 July 1921, L.S. Klinck to H.R. Christie.

17 UTA, B1983-0022/002(107), 11 July 1921, H.R. Christie to J.H. White.

18 UTA, A2004-0017/008(H. R. Christie), 18 July and 5 October 1921, C.D. Howe to H.R. Christie.

19 Ibid., 30 November 1921, H.R. Christie to C.D. Howe; ibid., 12 December 1921, Howe to Christie.

20 Ibid., 4 January 1922, C.D. Howe to R. Falconer; ibid., A2004-0025/012(T.W. Dwight), 11 February 1922, Howe to T.W. Dwight.

21 Ibid., B1983-0022/002(107), 2 and 4 March 1922, H. R. Christie to J. H. White; ibid., A2004-0025/008(H.R. Christie), 4 and 18 March 1922, Christie to C.D. Howe; ibid., 11 and 29 March 1922, Howe to Christie; UBCA, President's Office, Reel 34(Dean-FAS), 22 March 1922, A.B. Connell to President UBC; ibid., 22 March 1922, G.H. Edgecombe to President UBC.

22 Ibid., Reel 4(Ce-Cl), 1922-1923 Applied Science [Budget]; ibid., ca. March 1922, Notes for Dean Brock; ibid., Some alternative proposals discussed with the Honourable the Minister of Education on March 30 ${ }^{\text {th }}$, 1922, by L.S. Klinck; ibid., ca. March-April 1922, notes.

23 UTA, A2004-0025/008(H.R. Christie), 8 and 9 May 1922, H.R. Christie to C.D. Howe; ibid., 19 May 1922, Howe to Christie; ibid., 23 May 1922, Howe to R. Falconer.

24 Ibid., 19 June 1922, H.R. Christie to C.D. Howe; ibid., 29 June 1922, Secretary for Faculty of Forestry to F.A. Moure; UBCA, President's Office, Reel 3(Dean-Applied Science), 22 March 1922, A.B. Connell and G.H. Edgecombe to President of UBC; ibid., ca. June 1922, To the Head of the Department of Forestry ... ; ibid., 22 June 1922, R.W.S. Brock to L.S. Klinck.

25 UTA, A2004-0025/008(H.R. Christie), 30 July and 26 [2] September 1922, H.R. Christie to C.D. Howe.

26 Ibid., A1967-0007/077(C. D. Howe 1922-23), 10 October 1922, Howe to R. Falconer; UBCA, President's Office, Reel 1(H.R. Christie), 14 July 1922, Acting President to Christie; ibid., Reel 34 (FAS 1921-1922), 29 May 1922, Notes for L.S. Klinck.

27 UTA, A1967-0007/077 (C.D. Howe 1922-23), 10 October 1922, Howe to F.A. Moure; ibid., A1972-0035/151 (unlabelled), 14 November 1922, Howe to L.S. Webb; ibid., A2004-0017/016(J. D. Gilmour), 3 January 192[3], Howe to J. D. Gilmour.

28 UBCA, Malcolm Knapp, 1(1923-1924), 21 April 1923, M. Knapp to J.G.G. Morgan; ibid., 28 April 1924, Knapp to H. Winkenwerder; ibid., 16 October 1924, Knapp to G.M. Cornwall; ibid., 5 November 1924, Knapp to Percy; ibid., 2 (Achievements of UBC Forestry Graduates, 1971), Knapp's notes on the origins and early history of forestry education at UBC; ibid., President's Office, Reel 34(Dean-FAS), 24 October 1922, Chairman to R. W. S. Brock; ibid., Reel 4 (Ce-Cl), 1922-1923 Applied Science [Budget]; ibid., Board of Governors' Minutes, 30 April 1923; UTA, B19830022/002(107), 17 November 1925, H.R. Christie to J.H. White. 
29 UBCA, President's Office, Reel 7(FO), 15 November 1921, P. Caverhill to H.R. Christie; ibid., 23 May 1924, Christie to L.S. Klinck; ibid., Reel 9(Forest Reserve Lands, Dept of - 1925), all documents; ibid., Malcolm Knapp Papers, 6, Campus Forest - History of Logging, all documents; ibid., 3(Association - UBC Forest Club, 1930-1959), The UBC Forest Club Annual, No. 1, Vol. 1.

30 UBCA, Malcolm Knapp, 1(1927), all documents; ibid., 1(1931), 24 September 1931, M. Knapp to H.P. Baker; ibid., Board of Governors' Minutes, 1925-1926, passim.

31 Ibid., President's Office, 11-6, 3 February 1917, M.A. Grainger to F.F. Wesbrook; ibid., 5 February 1917, Wesbrook to Grainger; ibid., Reel (13), 26 January 1921, H.R. Christie to Registrar; ibid., Reel 15(F), ca. 1922, UBC_FAS — Department of Forestry, Information Concerning the Course in Forest Engineering; ibid., 7 March 1922, H.R. Christie to A.T. Cushing.

32 Logan, 110-120; UBCA, President's Office, 11-13, 21 January 1932, Memorandum Prepared by President and by the Deans of the Faculties ... .

33 UBCA, Malcolm Knapp, 3(Correspondence 1930-1939), 16 May 1932, M. Knapp to T.T. Munger and J.E Lodewick; ibid., Board of Governors' Minutes, 25 July 1932. It has been suggested that Christie's departure was hastened by another trying experience at this time, but the evidence is inconclusive in this regard. Smith, 107, recounts how Christie stood up as one of only two professors in the Faculty of Applied Science to defend a colleague whom the dean was trying to fire by using the budgetary crisis as a pretext for doing so. But Michiel Horn, Academic Freedom in Canada: A History (Toronto: University of Toronto Press, 1999), 93, describes what appears to be the same incident and notes that UBC's president intervened to foil the dean's plan, thereby rewarding Christie's courageous stance. It can thus be interpreted in diametric ways; this episode could have fortified — not drained — his commitment to remaining at his post, and conversely it could have been the final straw for Christie.

34 UTA, A2004-0025/008(H.R. Christie), 15 September 1932-Report of Forestry Department for 1932, UBC, enclosed in 24 October 1932, H.R. Christie to C.D. Howe.

35 UTA, A2004-0025/008(H.R. Christie), 9 January 1934, C.D. Howe to F.W. Walsh.

36 William C. Wonders, The 'Sawdust Fusiliers': The Canadian Forestry Corps in the Scottish Highlands in World War Two (Montreal: Canadian Pulp and Paper Association, 1991).

37 Arctic Vol. 53 No, 1 (March 2000), "Robert L. Christie (1926-1999)."

38 Smith, 108; UBCA, Board of Governors' Minutes, 1933-1935, passim; UBCA, Senate-Correspondence, 30(Report on UBC Forestry by P.M. Barr), December 1936, Instruction in Forestry at the University of British Columbia: A Report Submitted by P.M. Barr; ibid., 9 February 1937, Instruction in Forestry at ... Concluding Paragraphs of Report Dealing with the Subjects ... ; ibid., 3 May 1937, Recommendations to the Faculty of Arts and Science regarding the Barr Report on Forestry ... ; UBCA, Malcolm Knapp, Box 6 (Forestry Education at UBC — History Speech $(1946,1961)$ ), all documents; Logan, 124. 